\title{
OXFORD UNIVERSITY
}

\section{« Aquinas on Humility and Relational Greatness »}

\author{
Author \\ Andrew Charles Pinsent
}

A chapter submitted for

Routledge Handbook on the Philosophy of Humilityc

Mark Alfano, Michael P Lynch, Alessandra Tanesini, eds. 


\begin{abstract}
Humility is a practically orphaned virtue in contemporary virtue ethics, and its theological associations in classical and medieval texts do not, at first glance, commend humility in a secular world. In response, I examine in this chapter the place accorded to humility in Aquinas's relational virtue ethics. I begin by showing how the four species of pride he identifies inhibit flourishing from both a first- and second-person perspective, and how Aquinas's defends both humility as a guardian of relationships and a concomitant virtue of greatness. I conclude by observing how Aquinas's account of humility also transposes into a more secular framework, given the need for a disposition to protect the many interpersonal relationships and their fruitfulness that are associated with human flourishing.
\end{abstract}

\title{
I \\ The orphaned virtue of humility
}

Humility occupies an anomalous position in contemporary society and virtue ethics, to the point that there is some doubt over whether it should be regarded as a virtue at all. The attributes that are often associated with humility, such as being low, deferential and submissive, are rarely considered praiseworthy and go against the grain of a world in which it is proclaimed that we can be whatever we want to be. Moreover, it is challenging to find exemplars of humility, given the suspicion that if someone is prominent enough to be considered as an exemplar, that very prominence would seem to refute being humble. Given also that the path to humility is associated with humiliation, one of the least desirable experiences of life, why then should anyone bother with humility at all? Expressed in rhetorical terms, in the spirit of Nietzsche, shoudn't we reach for the stars rather than crawl in the dust?

The effects of these dire connotations are compounded by the lack of a wholly satisfactory account of humility within many influential accounts of virtue ethics. Humility is notoriously absent from Aristotle's Nicomachean Ethics, which MacIntyre has described as the canonical text of the Western tradition of virtue ethics, ${ }^{1}$ and it has proved difficult to retrofit humility into an Aristotelian framework as a mean between two vicious extremes. After all, in what sense is humility a virtuous mean, given that humility conveys the sense of an extravagance of self-giving or self-emptying? And the notion of a

Alasdair MacIntyre, After Virtue: A Study in Moral Theory, Third Edition, 3rd ed. (University of Notre Dame Press, 2007$), 147$. 
disposition to self-giving or self-emptying raises the additional question of how humility is conducive to the fullness and completion associated with human flourishing, the traditional goal of the most influential kinds of virtue ethics. But it is also challenging to see how humility fits in with most alternative approaches to virtue ethics, such as agent-based, exemplarist, or target-centred accounts.

One partial exception to the orphaning of humility might be virtue ethics in the Platonic tradition, insofar as this tradition emphasizes the way in which good agency presupposes the contemplation of the Form of the Good. ${ }^{2}$ Given the focus on a relationship to that which is supremely good, humility in relation to this supreme good might then be regarded as a disposition that is proper to human perfection. For this reason, it should not come as a surprise that one of the few classical references to humility is not to be found in the Aristotlelian corpus but in the following passage from Plato's Laws IV, 716a-b, a text that can also be found in citations by Christian authors in the early patristic era ${ }^{3}$ :

ATHENIAN. Now, then, our address should go like this: 'Men, according to the ancient story, there is a god who holds in his hands the beginning and end and middle of all things, and straight he marches in the cycle of nature. Justice, who takes vengeance on those who abandon the divine law, never leaves his side. The man who means to live in happiness latches on to her and follows her with meekness and humility (tapeinotês). But he who bursts with pride, elated by wealth or honors or by physical beauty when young and foolish, whose soul is afire with the arrogant belief that so far from needing someone to control and lead him, he can play the leader to others - there's a man whom God has deserted. And in his desolation he collects others like himself, and in his soaring frenzy he causes universal chaos. Many people think he cuts a fine figure, but before long he pays to Justice no trifling penalty and brings himself, his home and state to rack and ruin. Thus it is ordained. What action, then, should a sensible man take, and what should his outlook be? What must he avoid doing or thinking?'

CLINIAS. This much is obvious: every man must resolve to belong to those who follow in the company of God. ${ }^{4}$

Timothy Chappell, Knowing What To Do: Imagination, Virtue, and Platonism in Ethics (Oxford; New York: OUP Oxford, 2014$), 295$.

See, for example, Clement of Rome, Stromata, II, 22; Origen, Against Celsus, VI, 15.

Plato, Laws, IV, 716a-b, trans. Trevor J. Saunders, in Plato: Complete Works, ed. John M. Cooper and D. S. Hutchinson, (Hackett Publishing Company, 1997), p. 1402. First published by Penguin Books Ltd., 1970. 
According to this text, which mentions tapeinotês ('humility') explicitly in relation to God, the person who bursts with pride, and who thinks that he has no need of someone to control and lead him, is deserted by God, losing friendship with God. ${ }^{5}$ Such persons play the leader to others, produce chaos and swiftly bring ruin on themselves, their families and cities. On this account, humility is a necessary concomitant of human flourishing, insofar as it protects against the personal and social ruination caused by pride.

Plato in this passage emphasizes some significant dangers from a lack of humility, but his emphasis on the loss of divine favour underlines another important point about humility, namely that it is theological texts, or at least theological themes in philosophical texts, that have typically championed humility. This association is reinforced by the frequency with which humility is mentioned in key texts of revealed theology. For example, Jesus in the Gospel of Matthew says, "Take my yoke upon you, and learn from me; for I am gentle and humble in heart, and you will find rest for your souls" (Matthew 11:29 NRSV), ${ }^{6}$ which not only underlines the importance of humility in relation to God, but makes the utterly unintuitive assertion that God incarnate is also humble, and in an exemplary fashion. The First Letter of Peter says, "Humble yourselves therefore under the mighty hand of God, that in due time he may exalt you" (1 Peter 5:6), and the Letter of James reminds us that, "God opposes the proud, but gives grace to the humble" (James 4:6). A similar emphasis runs through the whole Christian tradition. References to humility and its importance can readily be found in the texts of patristic authors, scholastic theologians and doctors of the church. Cassian, for example, refers to humility as the "the mother of all virtues and

\footnotetext{
5 The connection between Plato's conception of humility and being a friend of God is also made clear in the subsequent paragraph, Laws IV, 716c-d. "On this principle the moderate man is God's friend, being like him, whereas the immoderate and unjust man is not like him and is his enemy," ibid.

6 Citations from Scripture are taken from the Revised Standard Version (RSV) unless marked 'NRSV', indicating the New Revised Standard Version. For this passage, the NRSV has been used since it translates tapeinos explicitly as 'humble'.
} 
the surest foundation of the whole spiritual superstructure,"7 and Augustine calls it the "safe and true way to heaven ... which lifts up the heart to the Lord." 8

The ubiquity of humility in the theological tradition does not, however, necessarily commend humility in the contemporary and more secular world. Indeed, the close association of humility with theological faith, and its decline along with faith, can in fact be interpreted as lending support to a fairly standard critique, along Nietzschean lines, that humility is bound up with Judeo-Christian "slave morality" and lacks the nobility of the strong-willed. On such an account, humility has been orphaned by the decline of faith and, as the life of faith fades, perhaps also humility deserves to fade and be forgotten.

Before dispensing with humility, however, it is at least prudent to examine what its most able defenders have to say. In this chapter, I examine the work of St Thomas Aquinas (d. 1274), who incorporated humility within his most mature and detailed account of virtue ethics in his Summa theologiae (ST) II-I.55-89 and II-II.1-170. I analyse humility and its opposing vice of pride, and I conclude by examining briefly the prospects for a secular transposition of Aquinas's account.

\section{II \\ Humility and pride}

Within the vast account of ST II-II.1-170, with its eight hundred and fifteen articles, Aquinas devotes five questions (qq.161-165) comprising twenty-two articles on humility and its opposing vice of pride. Aquinas's principal treatment of humility is covered in the six articles of q.161, followed by pride in general in q.162, and pride in the special case of the first sin in qq.163-165.

Cassian, “Conferences,” II, 19, 2, trans. Gibson, E., in The Early Church Fathers and Other Works (Scotland: Wm. B. Eerdmans Pub. Co, 1867).

$8 \quad$ Augustine, “City of God,” XVI, 4, trans. Dods, M., in The Early Church Fathers and Other Works. 
In article q.161 Aquinas argues, first, that humility is a virtue (a.1); that humility principally moderates the movement of the appetite rather than the judgment of reason (a.2); that by humility, a person ought to be subject to every neighbor, in respect of that which the latter has that is of God (a.3); and that humility is part of the virtue of temperance since it suppresses impetuous tendencies (a.4). He then ranks humility, placing it after the theological virtues, intellectual virtues, and after justice, especially legal justice, but before all other virtues (a.5). Finally, he interprets and validates an ancient guide to humility, namely the twelve degrees of humility in the Rule of St Benedict (a.6).

Aquinas's descriptions of humility in itself do not seem to contain anything unusual or particularly insightful, but the broader context does present some surprises. For example, although Aquinas describes the virtue of humility in terms of a praiseworthy self-abasement to the lowest place (q.161, a.1), he argues in ST II-II.129-133 that there is also a Christian virtue of greatness, namely magnanimity, which he describes using language drawn largely from Aristotle. There is also, of course, a vice associated with certain attitudes towards greatness, namely pride, the details of which highlight the value of humility.

What is pride and why is it a problem, if it is a problem? The latter question is not rhetorical, given that there are at least some instances in which pride describes something commendable, as in the case of someone saying to parents who are watching their child excel, "You must be so proud!" Moreover, it has

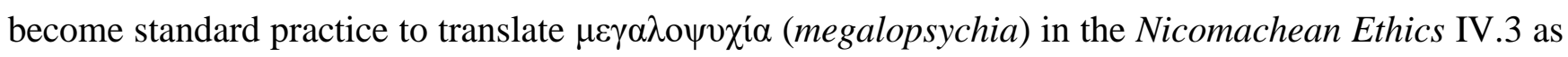
'pride', in which context it is hailed as a virtue concerned with great things. ${ }^{9}$ In this context, Aristotle describes the proud person as someone who thinks himself worthy of great things, and who is, in fact, worthy of them (NE.IV.3.1123b1-2). The proud man, he states, although extreme in respect of the

An influential example of the translation of megalopsychia as 'pride' is that of W. D. Ross and J. O. Urmson in Jonathan Barnes, Complete Works of Aristotle, Volume 2: The Revised Oxford Translation (Princeton, NJ: Princeton University Press, 1998), 1173-1776. 
greatness of his claims, does in fact observe the proper mean of virtue, insofar as what he claims is in accordance with his merits (NE.IV.3.1123b13-15).

On this account, pride is a virtue of greatness, and the proud man must be good in the highest degree, and the truly proud man must be good. Given that pride, in this context, is understood as a superlative good, in what sense or senses can it be a moral failing?

The task of shedding light on this question is made easier by considering what, precisely, is meant by pride when it is analyzed as a vice. Aquinas in ST II-II.162.4 defines four kinds of pride, drawing from a list set down in the patristic era by Pope St Gregory I. The following statements make use of these definitions but modify the wording slightly to highlight the connections of pride, relatedness and gift: ${ }^{10}$

P1 Ascribing an excellence to oneself that one does not possess.

P2 Thinking that one has acquired for oneself some excellence that one has received as a gift.

P3 Thinking that some excellence that one has received as a gift is due to one's own merits.

P4 Thinking that some excellence that one possesses is greater insofar as others do not have it.

One striking point from this list is that there is nothing in these definitions that excludes one from actually being great, or from knowing genuinely that one is great. This consideration leads to a first and important conclusion, namely that being proud in the Aristotelian sense does not necessarily mean that one is proud in Aquinas's sense of having one or more of the four species of pride listed above.

I have drawn these definitions, and some of the subsequent analysis, from my earlier work, Andrew Pinsent, "Humility," in Being Good: Christian Virtues for Everyday Life, ed. Michael W. Austin and Douglas Geivett (Eerdmans, 2012), 250-55. 
On what grounds, then, are P1-P4 to be considered as vices? On the basis that virtues conduce to flourishing and vices are defined as such as dispositions that impede that flourishing, it is important to examine in what senses, if any, the various species of pride might impede personal flourishing.

As a first example, P1 pride involves misjudging one's own excellences, which is itself a serious flaw insofar as it marks a lack of intellectual development. Moreover, choices made on the basis of an exaggerated and unwarranted estimate of personal excellence risk going awry. In extreme cases this may even prove destructive to one's person, family or society, as in the case of the skier who overestimates her ability on a dangerous ski slope, or the military general whose self-belief is exaggerated to the point of ignoring all views contrary to his own. More subtly, a person who thinks she already has some particular excellence will not strive for it for herself or from others. The person who believes erroneously he is already a great pianist or or philosopher will not be ready to receive instruction from others and strive for improvement. One can therefore consider that P1 pride is unwise even from the point of view of enlightened self-interest, given that it will tend to impede personal flourishing.

The other species of pride have similar drawbacks. P2 pride involves a recognition of genuine excellence but fails to recognize the correct cause. A person with P2 pride may actually consider himself the cause of a particular excellence, as when a person delights in a scientific breakthrough he has made when the seminal idea really came from someone else. More subtly, even when he does not actively think he has caused his own excellence, he may simply delight in the excellence but be forgetful of the person who has brought this about. Whatever else may be said, that kind of misattribution and forgetfulness makes it less likely that the person with P2 pride will be a recipient of further gifts in future which is, once again, detrimental to the attainment of further excellence.

The person with P3 pride acknowledges a personal excellence and its cause correctly but will tend to regard herself as at least the cause of the cause of her own excellence. Of course, for some kinds of 
excellence this assessment may be correct in part, as in the many kinds of sports and activities that require dedicated practice. But there are also many kinds of excellences or causes of excellence that are more in the manner of undeserved gifts, such as the loving care that is usually given to children by their parents, or the divine gifts that are generally regarded as necessary for a successful outcome of the Christian life. ${ }^{11}$ In such cases, it is inappropriate to think of these gifts as things one deserves or that are owed to oneself. Indeed, if one persistently treats undeserved gifts as if they are owed to oneself in the manner of a contract, the person with $\mathrm{P} 3$ pride is once again unlikely to be the recipient of further gifts in future, which is once again detrimental to the attainment of greater excellence.

P4 pride involves thinking that some excellence that one possesses is greater insofar as others do not have it, which is closely linked to what is today called schadenfreude, that is, taking pleasure, joy, or self-satisfaction from the troubles, failures, or humiliation of others. Schadenfreude is frequently described as a secret or guilty pleasure, implying an inherent awareness that enjoying this kind of pleasure reflects badly on oneself. But whatever else may be said about $\mathrm{P} 4$ pride, it does at least involve the misjudgment that one's own success, at least to some degree, is measured by the failures of others, like taking an extra-large slice of a shared cake. By contrast, if the good one seeks is a virtuous life, then the failures of others are in fact likely to be detrimental to this goal. After all, it is typically easier to be a virtuous person in a society of other virtuous persons, compared to being virtuous in a society of the vicious. On this account, the failures of others desired by $\mathrm{P} 4$ pride are, in fact, detrimental to oneself in an absolute sense, whatever the short-term advantage one gains over others in a relative sense.

In summary, all of these species of pride involve some kind of misjudgment of truth, a misjudgment that is itself an anomaly in a fully-formed life. But if the desired good of such a life is some kind of superlative greatness, then what is also striking is that all four kinds of pride will, in various ways, tend

P2 pride, in the context of the goal of salvation, corresponds to the ancient heresy of Pelagianism, that one can gain salvation through one's own efforts, while $\mathrm{P} 3$ pride maps onto semipelagianism, that one can merit the grace required for salvation in some way. 
to frustrate the attainment of that greatness. On this account, it is not only possible to be great and to be aware of one's own greatness without being proud in the senses meant by Aquinas, but these various dispositions of pride will in fact tend to inhibit genuine personal greatness. On this account, not only is there the possibility of compatibility between pride in the Aristotelian sense and an absence of pride in Aquinas's sense, but the absence of pride may actually be a precondition of greatness.

\section{III Second-person consequences of pride}

The section above considered the harm to oneself of pride, understand in terms of the four species listed by Aquinas, but it is commonly understood that pride has second-person as well as first-person consequences, insofar as it has an impact on relationships with other persons.

As a first example, P1 pride, to ascribe an excellence to oneself that one does not possess, implies a self-admiration that is excessive and beyond reason, corresponding to the dictionary definition of narcissism. ${ }^{12}$ As is well known and is now well documented, persons who are obsessed with themselves in a narcissistic fashion are less likely to be capable of any genuine love of others, and there is an extensive and growing literature on the toxicity of narcissism for relationships. ${ }^{13}$

$\mathrm{P} 2$ pride is also damaging to relationships insofar as it prevents a person from acknowledging that a gift is a gift, or the relationship of the gift with a giver, or the giver as a giver. This failure will scarcely be appreciated by the giver, and is unlikely to be helpful to the relationship. Therefore, as in the case of

12 "Narcissism, n.," in OED Online, Oxford English Dictionary (Oxford: Oxford University Press), accessed June 10, 2019, https://www.oed.com/view/Entry/125088.

13 See, for example, Jean Twenge and W. Keith Campbell, The Narcissism Epidemic: Living in the Age of Entitlement (New York London Toronto Sydney New Delhi: Atria Books, 2010).; Brandon Grey, Narcissistic Relationship: Ultimate Guide to Torture a Narcissist. Recovery from the Epidemic Narcissism, Emotional Abuse and Personality Disorder. The Revenge for Lovers (Also for Parents). (Independently published, 2019). 
P1 pride, which has the characteristic of self-satisfied closure, P2 pride is also 'cold' in the sense that it is deleterious to relationships or fails to establish or acknowledge a relationship that should exist.

P3 pride, thinking that some excellence that one has received as a gift is due to one's own merits, which can imply that what one has received is, in effect, owed to oneself because of what one is or what one has done. If one thinks of the relationship in this way, then the gift is received in the manner of a contractual transaction. As a consequence, there is also a kind of 'coldness' about P3 pride, as in the case of a marriage in which the spouses have been reduced to bickering about the distribution of rights and responsibilities. Although a relationship exists it lacks the characteristics of genuine love in the sense of friendship, in which the twofold desires for the good of the other and for union with the other are not conditional upon receiving some good from the other, even though some minimal good from the other, namely openness to the friendship, is earnestly desired. P3 pride therefore acknowledges only an inadequate relationship, akin to a contractual relationship rather than friendship.

P4 pride also damages relationships, but principally because the person with P4 pride fails to understand the nature of the gift in the relationship with a giver. Perhaps the clearest illustration of a failure to grasp this point can be seen in one of the parables of Jesus, the story of the Pharisee and the tax collector:

Two men went up into the temple to pray, one a Pharisee and the other a tax collector. The Pharisee stood and prayed thus with himself, "God, I thank thee that I am not like other men, extortioners, unjust, adulterers, or even like this tax collector. I fast twice a week, I give tithes of all that I get." But the tax collector, standing far off, would not even lift up his eyes to heaven, but beat his breast, saying, "God, be merciful to me a sinner!" I tell you, this man went down to his house justified rather than the other; for every one who exalts himself will be humbled, but he who humbles himself will be exalted (Luke 18:10-14).

In this parable, the Pharisee acknowledges God as the cause of what he has and thanks God for his gifts, but part of his delight is not just that he has these gifts but that others lack them. But given that being right with God is not something that diminishes by being shared with others, the Pharisee's attitude shows 
that he does not really understand the nature of the divine gifts to which he aspires. Moreover, the fact that the Pharisee secretly takes delight in the apparent relative failure of the tax collector shows that he is not, in fact, aligned with the desire of God that all should be saved, and hence is not in that harmony with God that corresponds to a state of divine friendship. Hence Jesus warns that it is not the Pharisee but the tax collector, who simply begs for God's mercy, who goes home justified. ${ }^{14}$

\section{IV \\ Relational Greatness}

The considerations above underline how pride, understood in terms of the four species listed by Aquinas, has the potential both to inhibit any greatness that one would want for oneself and is toxic for one's relationships with others. But the dangers of pride are compounded when these two sets of goods coincide, in other words when the greatness that one seeks consists principally in the flourishing of a relationship. The coincidence is central to Aquinas's own account of human flourishing, outlined in ST II-II.1-170, which is entirely ordered by and towards caritas or divine love, which Aquinas describes in terms of friendship (ST II-II.23.1), first and principally with God but also with other persons.

Given that pride is toxic to friendship, for the reasons highlighted above, pride is wholly antipathetic to human flourishing in Aquinas's account. Moreover, pride will also tend to impede even the first steps towards the goal of flourishing since, as I have argued extensively elsewhere, Aquinas's entire account of virtue ethics is built around what psychologists today have called 'joint attention', in which one permits oneself to be moved by a second person to align psychologically with that second person. ${ }^{15}$ Given that,

14 I note in passing that Rebecca Konyndyk De Young has argued that humility is a disposition to consider oneself small in relation to God and magnanimity as a virtue of 'acknowledged dependence' on God. See Rebecca Konyndyk de Young, “Aquinas's Virtues of Acknowledged Dependence: A New Measure of Greatness," Faith and Philosophy 21, no. 2 (2004): 219. This solution is consistent with the rejection of P1 and P2 pride, but does not, I believe, fully explain the rejection of P3 and P4 pride, since, for example, the Pharisee in the parable acknowledges dependence on God but still suffers from $\mathrm{P} 4$ pride.

15 Andrew Pinsent, The Second-Person Perspective in Aquinas's Ethics: Virtues and Gifts (New York; Abingdon, UK: Routledge, 2012), 3163. For an introduction to the psychology of joint attention, see, for example, Naomi Eilan et al., eds., Joint Attention: Communication and Other Minds: Issues in Philosophy and Psychology (Oxford: Clarendon Press, 2005). 
in a state of pride, one resists being moved at all to align with another person, pride not only inhibits friendship but also the second-person relatedness ${ }^{16}$ that is a precondition of and oriented towards friendship. On this account, pride leaves one cold, isolated, and unable to grow in virtue.

Given the toxicity of pride for flourishing in Aquinas's highly relational account of virtue ethics, one can perceive why humility has a natural and important place in his account of virtue ethics, given that humility specifically protects the second-person relatedness that is the means to continue and develop in virtue as well as the friendship or divine love that is the goal or fruition of virtue.

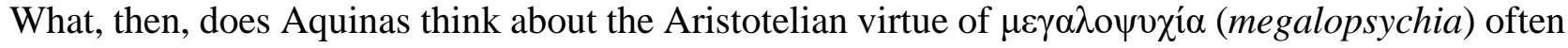
translated today as 'pride'? As noted previously, nothing in the four species of the vice of pride prevents persons from being great or knowing that they are great. Moreover, as noted previously, in ST II-II.129133, Aquinas specifically defends this virtue of greatness, not under the name of 'pride' but 'magnanimity' from the Latin magnanimitās, from magna "great" and animus "soul, spirit", which is a

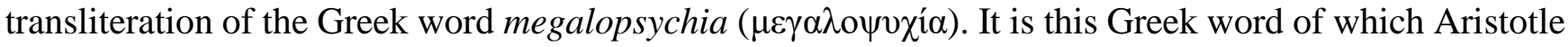
writes in NE.IV.3.1123b1-2, "Now a person is thought to be great-souled if he claims much and deserves

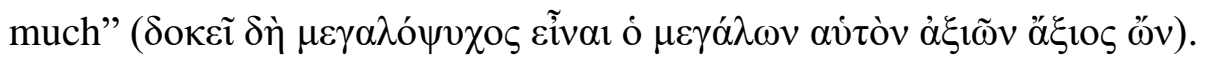

The introduction of a good pride, magnanimity, helps to avoid some linguistic confusion and it is notable that Aquinas follows Aristotle in describing magnanimity as being about honor (ST II-II.129.1), and specifically about great honor (129.2). He further argues that magnanimity is a virtue (129.3), and since honor is a reward of every virtue, magnanimity is about doing great deeds in the actions associated with every virtue. On this account, magananimity pertains to every virtue, making their actions greater

I use the term 'relatedness' rather than 'relationship' so as not to exclude short-term and momentary interactions in which one aligns with second persons. I am grateful to advice from Peter Hobson for this practice. 
and worthy of great honor (129.4 ad 3). Hence Aquinas can and does defend the disposition to greatness, using descriptions drawn largely from Aristotle, while also opposing the fourfold vice of pride.

Despite this apparent resolution, however, it must be admitted that there is some reluctance to translate megalopsychia as magnanimity today, and to deny that the Christianised virtue of magnanimity captures what Aristotle meant by megalopsychia. The reason, I think, is that some of the characteristics of Aristotle's great-souled person, which are also defended by Aquinas, do seem to clash with Christian ideals, including in particular: being unmindful of favors; being remiss and slow of action; employing 'irony' (eironia) towards many; being unable to associate with others; holding to barren things rather than to those that are fruitful $;{ }^{17}$ considering oneself worthy of great honors, and yet despising such honors; not being cast down by dishonor, and despising such dishonor, because it is undeserved; ${ }^{18}$ having complete confidence in achieving greatness; being perfectly free from fear; making use of goods of fortune, but neither being uplifted much by having them, nor downcast much by losing them. ${ }^{19}$ At first glance, such characteristics convey the impression that the magnanimous person is aloof, disdainful and arrogant, contrary to humility and love.

The Aristotelian attributes of megalopsychia as described above could, it must be admitted, be ascribed to someone who is viciously proud. Such a person, with a distorted assessment of the first person at the heart of his or her world, may well act with aloofness, disdain, and arrogance. But at the heart of Aquinas's virtue ethics is the relationship with God in the manner of a second person, and it is this second person who is at the heart of the Christian life. On this interpretation, many of the

17 In ST II-II.129.3 arg 5. In his response to this objection, Aquinas claims that such characteristics, with certain qualifications, call not for blame but for very great praise, insofar as they belong to a magnanimous person. Note that 'irony' here denotes the Greek eironia, namely dissimulation of one's own good; cf. ST II-II.113.1 arg 1.

18 ST II-II.129.2 ad 3.

19 ST II-II.129.6, 7, 8. 
Aristotelian attributes of megalopsychia can be given an alternative reading, not in terms of isolated

arrogance but in terms of confident second-person dependence, as I have written elsewhere as follows,

... a child that is confident in her parent is not going to be over-anxious about what she possesses herself in order to complete some difficult task, and can afford to hold to 'barren' things, for their own sake, rather than those that are 'fruitful'. Such a person can also be free from fear and make use of goods of fortune, but neither being uplifted much by having them, nor downcast much by losing them. Being remiss or slow of action and 'irony' can also be understood in terms of confidence that is secondpersonal, rather than a first-personal confidence that depends on one's own resources, efforts and time. With regard to honor, such a person can consider herself worthy of great honours while treating the actual bestowal of such honours, or dishonours, lightly, since the approval sought is not from civic society but God. Similarly, 'being unable to associate with others' can be interpreted as a different mode of relationship with God which may set a person apart, at least from certain other associations. Even being 'unmindful of favours' can be accommodated within a second-personal account, if being mindful of favours is interpreted as implying a balance sheet approach to giving and receiving favours, an approach that is pertinent to a third person or contractual approach to favors rather than freely given gifts. ${ }^{20}$

In other words, while one can read Aristotelian megalopsychia in terms of first-person arrogance, which is perhaps a typical reading today, one can also interpret it in terms of the second-person confidence of a beloved child with a parent, stemming from the security of a relationship with God made possible through love, humility, and the divine gifts of grace. On this account, whatever Aristotle's own views on this matter, it is possible to incorporate his claims into an account of magnanimity that is both compatible with and dependent upon humility with respect to the divine source of all that is good.

\section{V \\ The Secular Transposition}

For Aquinas, the principal second person to whom we are meant to relate in the life of grace is God, with whom joint attention is made possible thanks to certain divine gifts, and human flourishing is

20 Pinsent, The Second-Person Perspective in Aquinas's Ethics, 82. 
organized around the principle of friendship with God. But can this account of theological flourishing retain any validity if it is transposed to a more contemporary and secular context?

The answer, I think, is straightforwardly affirmative. Just as the metaphor of human relationships is used to understand the theological principles of the life of grace, so also some of the lessons of flourishing in the theological life of grace can be applied back to human development. In particular, it has been argued that joint attention with other human persons, starting with simple shared actions like pointing, gaze following and turn-taking games, plays an important role in child development, including the acquisition of language and character formation. ${ }^{21}$ Moreover, many parents will also be familiar with moral struggles of their own children, especially when children face a choice between aligning with their parents' wills to do some good thing and their tendency to resist aligning with their parent's will, as in the familiar case of a child refusing to say sorry after doing something wrong. The drama and appropriate virtues of the relationship with God, played out throughout Scripture, therefore have clear parallels with the more conventional and everyday drama of human development and relationships.

These considerations suggest that humility, although achieving prominence especially in a theological context, is scarcely restricted to relating to God as to a second person, as 'I' to 'you'. On the contrary, the commonsense view that it is proper and good for human persons to relate to other persons as second persons, and the damage to relationships from the species of pride, underline how humility is also valuable in a more general and secular sense. Hence Aquinas's arguments that humility is inherently important and a prerequisite of greatness is not limited to the theological context. On the contrary, the point that G. K. Chesterton expresses in the following passage is broadly applicable:

If a man would make his world large, he must always be making himself small. Even the haughty visions, the tall cities, and the toppling pinnacles are the creations of

21 See, for example, Peter Hobson, The Cradle of Thought: Exploring the Origins of Thinking (New York: Oxford University Press, 2003). 
humility ... For towers are not towers unless we look up at them, and giants are not giants unless they are larger than we are.. .22

Chesterton's observations, as well as what has been written above, suggest that pride leads at most to a false, narrow and petty superiority. By contrast, humility strengthens the possibility of true friendship and greatness insofar as it opens us to relate personally with what is greater than ourselves. ${ }^{23}$

\section{BIBLIOGRAPHY}

Barnes, Jonathan. Complete Works of Aristotle, Volume 2: The Revised Oxford Translation. Princeton, NJ: Princeton University Press, 1998.

Chappell, Timothy. Knowing What To Do: Imagination, Virtue, and Platonism in Ethics. Oxford; New York: OUP Oxford, 2014.

Eilan, Naomi, Christoph Hoerl, Teresa McCormack, and Johannes Roessler, eds. Joint Attention:

Communication and Other Minds: Issues in Philosophy and Psychology. Oxford: Clarendon Press, 2005.

Grey, Brandon. Narcissistic Relationship: Ultimate Guide to Torture a Narcissist. Recovery from the

Epidemic Narcissism, Emotional Abuse and Personality Disorder. The Revenge for Lovers

(Also for Parents). Independently published, 2019.

Hobson, Peter. The Cradle of Thought: Exploring the Origins of Thinking. New York: Oxford University Press, 2003.

Jean Twenge, and W. Keith Campbell. The Narcissism Epidemic: Living in the Age of Entitlement. New York London Toronto Sydney New Delhi: Atria Books, 2010.

"Narcissism, n." In OED Online. Vol. Oxford English Dictionary. Oxford English Dictionary. Oxford:

Oxford University Press. Accessed June 10, 2019. https://www.oed.com/view/Entry/125088.

Pinsent, Andrew. "Humility." In Being Good: Christian Virtues for Everyday Life, edited by Michael

W. Austin and Douglas Geivett. Eerdmans, 2012.

- The Second-Person Perspective in Aquinas's Ethics: Virtues and Gifts. New York; Abingdon, UK: Routledge, 2012.

The Early Church Fathers and Other Works. Scotland: Wm. B. Eerdmans Pub. Co, 1867.

Young, Rebecca Konyndyk de. “Aquinas's Virtues of Acknowledged Dependence: A New Measure of Greatness." Faith and Philosophy 21, no. 2 (2004): 214-27.

22 Gilbert K. Chesterton, Orthodoxy, (London: Bodley Head, 1908), chap. III.

23 As noted in the text, I have drawn some of the material of this chapter from two earlier publications, namely Pinsent, "Humility," 242-64.; and Pinsent, The Second-Person Perspective in Aquinas's Ethics, 77-83. I am especially grateful for feedback and advice from Eleonore Stump for the preparation of these earlier works. 